Konovalova N., \& Dalecka S. (2016). Analysis and evaluation of capital adequacy in Latvian banking system. Copernican Journal of Finance \& Accounting, 5(1), 107-123. http://dx.doi.org/10.12775/ CJFA.2016.006

\author{
Natalia Konovalova* \\ RISEBA University \\ Snezhana Dalecka* \\ RISEBA University
}

\title{
ANALYSIS AND EVALUATION OF CAPITAL ADEQUACY IN LATVIAN BANKING SYSTEM
}

Keywords: Capital adequacy, Risk adjusted assets, Credit risk, Market risk, Operational risk, Buffer capital.

JEL Classification: G21, G32.

Abstract: Regulation of banking activity under economic insecurity conditions is one of key problems in our times and is acquiring a particular importance both for banks themselves and their shareholders and also for customers and depositors. Instability of economic situation gives birth to increasing risks faced by world banking system. And therefore in order to ensure reliable operation of commercial banks and prevent their vulnerability to economic insecurity, the supervisory bodies are continuously improving the methods of and approaches towards the management of bank risks accenting a paramount importance of own capital adequacy. A problem of how much capital Latvian commercial banks need to cover their risks remains one of most important in regulation and assessment of banking activity. Meanwhile, the principal direction to improve the capital adequacy ratio is the growth in its flexibility when determining the

Date of submission: November 3, 2015; date of acceptance: February 29, 2016.

* Contact information: natalija.konovalova@riseba.lv, RISEBA University, Meza street 3, Riga, LV-1048, Latvia, phone:+37129215208.

** Contact information: snezanaosmolovska@inbox.lv, RISEBA University, Meza street 3, Riga, LV-1048, Latvia, phone:+37129895698. 
value of risks inherent to various bank organisations. In the present research authors carry out the analysis of risks inherent in activity of Latvian commercial banks, indentifies the risk pattern within own capital of banks, discovers factors having impact upon the risk pattern as well as estimates the amount of capital necessary to cover risks in various groups of commercial banks.

Hypothesis - Stability of a banking system depends on the level of sufficiency of a bank capital.

The aim of the research: Evaluation of capital adequacy of Latvian commercial banks and correspondence of capital adequacy calculations to Basel Committee on Banking Supervision rules based on analysis of financials statements, identification of capital adequacy problems and developing recommendations on improving bank capital adequacy according to the effective and the planned Basel Committee on Banking Supervision requirements.

\section{RESEARCH METHODOLOGY AND INTRODUCTION INTO THEORETICAL FRAMEWORK OF BANK CAPITAL EVALUATION}

The study is methodologically basing on the observation and collection of financial information about activity of commercial banks, the analysis and synthesis of acquired data, the method of comparison between economic groupings, the ratio method as well as the method of graphic display of statistic information. The study employs the official statistical data of the Association of Latvian Commercial Banks, the commercial banks supervisory body (Financial and Capital Market Commission) as well as annual financial reporting of Latvian commercial banks.

The stability of a bank depends on a bank's capital, its quality and size. A bank's capital is a mandatory and integral part of its financial resources, and its development in the form of core capital is a required step even before establishing a commercial bank (Saksonova 2006). Practically every stage of a bank's business is directly or indirectly linked to the capital at the bank's disposal and its value. A bank's capital serves as one of determinants in the evaluation process of its stability. The adequacy of the bank's own funds provides for its financial stability and neutralises different risks inherent to a commercial bank's course of business (Greuning and Brajovic Bratanovic 2009). The size of a bank's capital is crucial not only for the safety of its customers, but also for the bank's own stability, avoiding the impact of short-term financial problems (Saksonova 2006). The capital also serves as an indicator of the bank's credit solvency, since the total amount of its assets may not exceed a certain capital adequacy limit, which means that the maximum amount of the bank's assets depends on the size of its capital. The size of capital greatly determines the 
bank's competitiveness. Since shareholders of a bank always seek to increase the profitability of their investments, the bank's endeavours to increase the profit reflect on prices of products and services it provides. On the other hand, a bank must attract a certain amount of customer deposits to be able to ensure full-scale lending operations, which is only possible, if the bank has gained public trust and that is possible with sufficient capital reserve. In case of sudden capital adequacy problems a bank may loose its competitiveness (Greuning, Brajovic Bratanovic 2009).

The American scientist Chorafas (2004), in his turn, believes that the main function of a commercial bank's capital is generation of bank's income and profit respectively, and provide for a possibility to cover unexpected operating losses of a commercial bank. American scientists Schooner and Taylor (2009) in their book „Global Bank Regulation: Principles and Policies” offer an identical definition, but in addition to that they stress the possibility to use capital of a commercial bank to cover possible losses caused by credit risk. American economists Greuning and Brajovic Bratanovic (2009) hold a view that capital adequacy level must be consistent with the risk level of the bank's operations. Latvian economist Kudinska (2005) holds a view that capital adequacy reflects resources of a bank's capital required as protection against credit risk and similar risks related to a bank's assets' portfolio and off-balance sheet items.

In the Financial and Capital Market Commission's regulations capital adequacy is defined as the amount of provisions to cover a bank's operating losses. They also elaborate that a capital requirement is an estimate of probable losses based on information available at the moment such estimate is made. The amount of a capital requirement depends on the amount of a bank's assets and their structure, as well as risks assumed by the bank. Almost all unmanaged risks cause losses, which, in their turn, cause volatility of capital adequacy. Thus to determine the amount of capital needed to cover risks a bank identifies risks included in the capital adequacy evaluation. A bank must evaluate all risks inherent to its business, including risks, for which minimum regulatory capital requirements are set, and the risks, for which no such minimum requirements exist (FCMC, 2014).

In 2010 Basel Committee announced the Third Basel Accord under the title "A Global Regulatory Framework for More Resilient Banks and Banking Systems". The aim of introducing Basel III requirements is strengthening of financial system and avoidance of financial practice leading to new global crises. The 
new regulations require increase of size of capital of banks, improving its quality and reducing interest in using financial instruments with high leverage. From the legal point of view Basel III standards are just recommendations for reforming banking regulation. But considering the fact that these rules were developed by central banks and financial market regulators of the strongest economies in the world, they actually serve as commercial practice regulation guidelines. Basel III does not supersede Basel II, but rather supplements it. The reform envisions considerable reviewing and improving of the existing, and introducing several new requirements. The document will have impact on changes in capital requirements. The changes are aimed at increasing capital quality of banks, coherence and transparency of capital basis, and strengthening of capital cover ratios for risks. Basel III rules are scheduled for implementation starting from 2013. The implementation process of standards began already in 01 January 2011. The observation stage lasted until the end of 2012. During that stage the new rules did not come into effect yet. They gradually started to come into effect from 01 January 2013 till 01 January 2019. The implementation was divided into several stages, with the deadline in 2019 (Table 1).

Fulfilment of the requirement most likely will create a need for additional capital and correspondingly reflect on financially weak Latvian commercial banks. Therefore estimates should be made in a timely manner to evaluate impact of these changes on bank capital requirements taking into consideration long-term strategy.

Table 1. Implementation schedule of Basel III rules

\begin{tabular}{|l|l|l|l|l|l|l|l|l|l|}
\hline \hline \multicolumn{1}{|c|}{$\begin{array}{c}\text { Names } \\
\text { of indicates }\end{array}$} & \multicolumn{1}{|c|}{$\mathbf{2 0 1 1}$} & $\mathbf{2 0 1 2}$ & $\mathbf{2 0 1 3}$ & $\mathbf{2 0 1 4}$ & $\mathbf{2 0 1 5}$ & $\mathbf{2 0 1 6}$ & $\mathbf{2 0 1 7}$ & $\mathbf{2 0 1 8}$ & $\mathbf{2 0 1 9}$ \\
\hline \hline $\begin{array}{l}\text { Minimum } \\
\text { Common } \\
\text { Equity } \\
\text { Capital Ratio } \\
\text { (CET 1 / RWA) }\end{array}$ & $\begin{array}{l}\text { Supervisory } \\
\text { monitoring }\end{array}$ & $\begin{array}{l}\text { Supervisory } \\
\text { monitoring }\end{array}$ & $3,5 \%$ & $4,0 \%$ & $4,5 \%$ & $4,5 \%$ & $4,5 \%$ & $4,5 \%$ & $4,5 \%$ \\
\hline $\begin{array}{l}\text { Capital } \\
\text { Conservation } \\
\text { Buffer }\end{array}$ & $\begin{array}{l}\text { Supervisory } \\
\text { monitoring }\end{array}$ & $\begin{array}{l}\text { Supervisory } \\
\text { monitoring }\end{array}$ & & $4,0 \%$ & $4,5 \%$ & $5,125 \%$ & $5,75 \%$ & $6,375 \%$ & $7,0 \%$ \\
\hline $\begin{array}{l}\text { Minimum } \\
\text { Common } \\
\text { Equity } \\
\text { Capital Ratio } \\
\text { plus Capital } \\
\text { Conservation } \\
\text { Buffer }\end{array}$ & $\begin{array}{l}\text { Supervisory } \\
\text { monitoring }\end{array}$ & $\begin{array}{l}\text { Supervisory } \\
\text { monitoring }\end{array}$ & $3,5 \%$ & $4,625 \%$ & $1,25 \%$ & $1,875 \%$ & $2,50 \%$ \\
\hline
\end{tabular}




\begin{tabular}{|l|l|l|l|l|l|l|l|l|l|}
\hline \hline \multicolumn{1}{|c|}{$\begin{array}{c}\text { Names } \\
\text { of indicates }\end{array}$} & $\mathbf{2 0 1 1}$ & $\mathbf{2 0 1 2}$ & $\mathbf{2 0 1 3}$ & $\mathbf{2 0 1 4}$ & $\mathbf{2 0 1 5}$ & $\mathbf{2 0 1 6}$ & $\mathbf{2 0 1 7}$ & $\mathbf{2 0 1 8}$ & $\mathbf{2 0 1 9}$ \\
\hline \hline $\begin{array}{l}\text { Minimum } \\
\text { Tier 1 } \\
\text { Capital Ratio } \\
\text { (T1C/RWA) }\end{array}$ & $\begin{array}{l}\text { Supervisory } \\
\text { monitoring }\end{array}$ & $\begin{array}{l}\text { Supervisory } \\
\text { monitoring }\end{array}$ & $4,5 \%$ & $5,5 \%$ & $6,0 \%$ & $6,0 \%$ & $6,0 \%$ & $6,0 \%$ & $6,0 \%$ \\
\hline $\begin{array}{l}\text { Minimum } \\
\text { Total Capital } \\
\text { Ratio } \\
\text { (TC/RWA) }\end{array}$ & $\begin{array}{l}\text { Supervisory } \\
\text { monitoring }\end{array}$ & $\begin{array}{l}\text { Supervisory } \\
\text { monitoring }\end{array}$ & $8,0 \%$ & $8,0 \%$ & $8,0 \%$ & $8,0 \%$ & $8,0 \%$ & $8,0 \%$ & $8,0 \%$ \\
\hline $\begin{array}{l}\text { Minimum } \\
\text { Total Capital } \\
\text { plus Capital } \\
\text { Conservation } \\
\text { Buffer }\end{array}$ & $\begin{array}{l}\text { Supervisory } \\
\text { monitoring }\end{array}$ & $\begin{array}{l}\text { Supervisory } \\
\text { monitoring }\end{array}$ & $8,0 \%$ & $8,0 \%$ & $8,0 \%$ & $8,625 \%$ & $9,25 \%$ & $9,875 \%$ & $10,5 \%$ \\
\hline \hline
\end{tabular}

S o u r c e : Basel Committee on Banking Supervision, June 2011.

\section{ANALYSIS OF FACTORS INFLUENCING CAPITAL ADEQUACY IN DIFFERENT GROUPS OF LATVIAN COMMERCIAL BANKS}

Before performing analysis of Latvian banking sector's capital adequacy level, evaluation of capital adequacy of Latvian banks in comparison to other European countries should be made. In 2013 capital adequacy of Latvian banking sector at the level of consolidation groups of banks exceeded the average level in EEZ member states (CAR - 15\%). In 2013 in EEZ states the aforementioned ratio reached only $15.0 \%$, whereas in Latvia it amounted to $18.94 \%$ (Figure 1).

Figure 1. Capital adequacy ratios of Latvian commercial banks

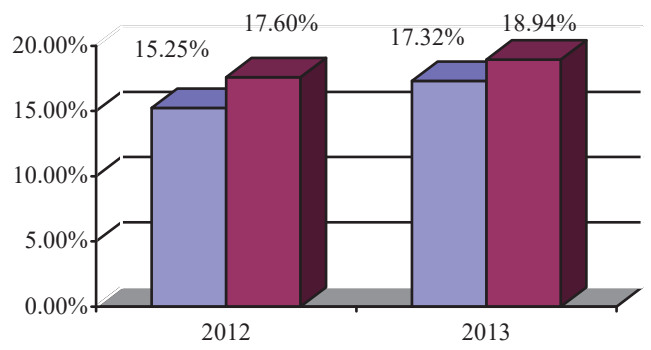

$\square$ Tier 1 capital adequacy ratio $\square$ Capital adequacy ratio 
At the beginning of 2014 the number of banks in the country shrank to 17 (in addition 9 branches of foreign banks operate in Latvia), because AS GE Money Bank, AS Unicredit Bank and AS Mortgage and Land Bank of Latvia changed their business strategy and decided to stop providing services on Latvian market. As a comparison, at the end of 201320 banks and 9 branches of foreign banks operated on Latvian market. According to 2012 statistics the number of commercial banks in Latvia for the most part shows a growth tendency and since 2001 has increased by $11.11 \%$. The data of 2013 does not indicate such positive tendency any more, since the number of banks during the year shrank by $15 \%$ (or by three banks). Interest of foreign investors in Latvian market in the long term remains at the same level, illustrated by the increased concentration of investments of non-resident shareholders in equity capital of banks registered in Latvia (Figure 2).

During the period of time from 2001 to 2013 concentration of foreign capital in Latvian banking sector on the average exceeded 56.69\%, and in 2013 reached $58.83 \%$. The majority of banks registered in Latvia have foreign (East and European) capital. In 2013 investments of investors from East in Latvian banks' capital reached $41.18 \%$ of the market (2012 - 30\%). Most of these shareholders are from Ukraine and Russia. Banks with qualifying holdings of European shareholders, in their turn, have $17.65 \%$ of Latvian banking market. Compared to 2012 their specific weight has dropped by 7.35\%, because AS UniCredit Bank (withdrawal of licence at the beginning of 2014) and AS Norvik bank left the East capital group of banks. At the end of 2013 Norvik bank strategic investor changed and a resident of Russia became the main shareholder of the bank (holding in equity capital - 51\%). As a result Norvik bank is now in the East capital group of banks, which increased their specific weight to $41.18 \%$ of the market in 2013 (Figure 2).

The most significant risk for banks still is credit risk, and at the end of 2013 credit risk capital requirement amounted to $89.24 \%$ of the total amount of capital requirements of Latvian banks (at the end of 2012 - 89.6\%). Market and operational risks make up a small part of capital requirement of banks $(10.76 \%$ - in 2013, 10.4\% - in 2012) and have no material impact on capital adequacy ratios. Just like in 2012 in 2013 capitalization of Latvian banking sector using breakdown in groups stayed high. Each group of banks optimized costs of attracted resources and partially repaid subordinated investments, thereby reducing by 119846 thousand EUR (in 2012 - 123364 thousand EUR) Tier 2 capital of Latvian banking sector and ensuring a rather small specific weight of it 
Figure 2. The structure of Latvian banking sector based on the number of banks broken down in groups of banks by capital ownership, 2001-2014

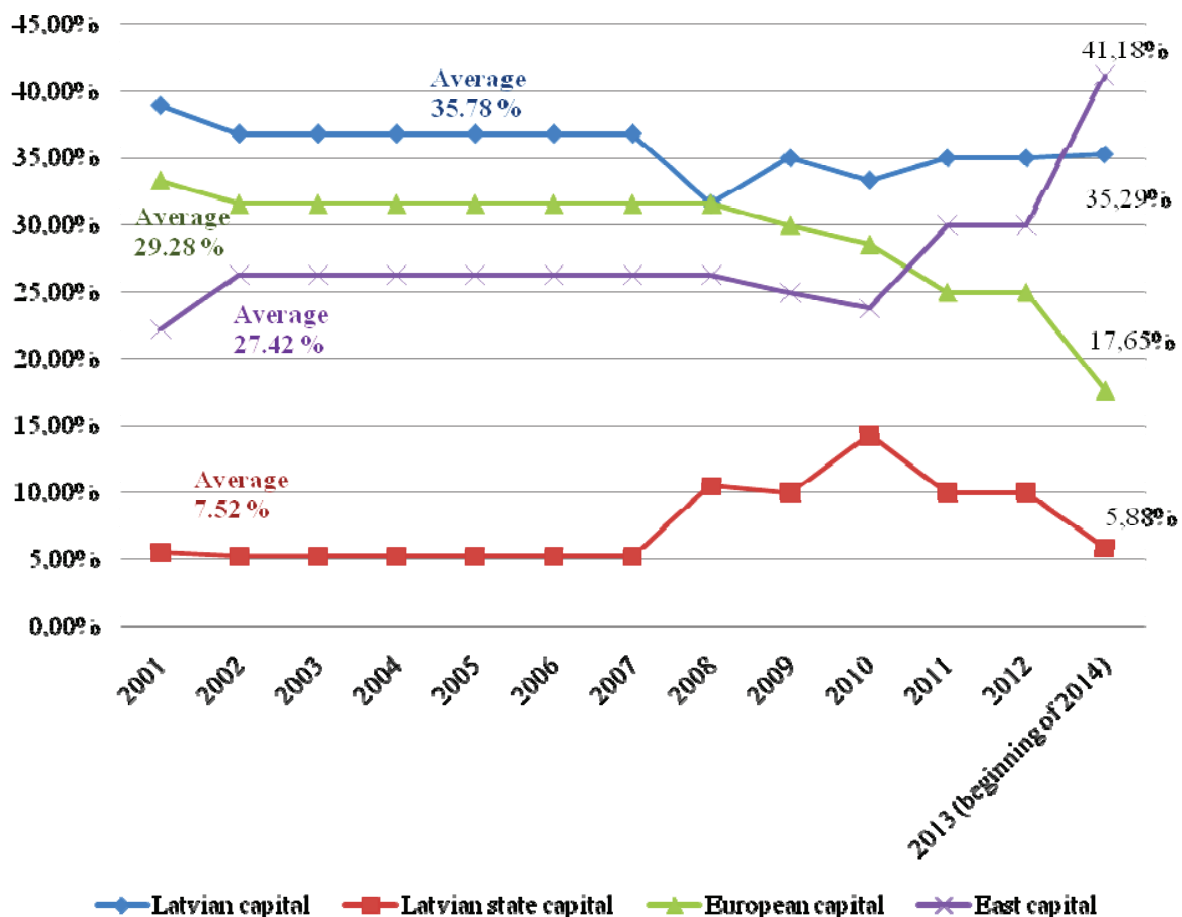

S o u r c e : created by authors based on consolidated annual reports of Latvian banks, 2001-2014.

in equity capital 15.22\% (in 2012 - 13.89\%). Evaluating equity capital distribution with the aim to determine the specific weight of foreign capital on Latvian market one should note that during the analysed period (2001 - 2013) equity capital in the banking sector amounted to 1622018 thousand EUR. The group of banks with European capital holds on the average 54.25\% of Latvian banking sector capital, the group of banks with Latvian capital $-27.75 \%$ and others (groups of banks with East and Latvian state shareholders) - 18.0\%. The capital structure of Latvian banks in each period is dominated by Tier 1 capital and at the end of 2013 constituted $85.53 \%$ (in 2012 - 87.15\%) of the total amount of capital in groups of banks. Comparing the present value of capital to the data of 2001 the total equity capital of banks at the end of 2001 amounted only to 
432054 thousand EUR, which is $83.82 \%$ less than in 2013 (in $2013-2668$ 435 thousand EUR). The specific weight of foreign capital in the equity capital of Latvian banks was already considerable at the time $-61.48 \%$. Groups of banks with European (56.36\%) and East (5.12\%) capital made up the indicated percentage share. The state of Latvia, in its turn, in 2001 was the sole shareholder of AS Mortgage and Land Bank of Latvia, and the bank's equity capital accounted only for $4.17 \%$ of the total capital of Latvian banks (Figure 3).

Figure 3. CAR breakdown in groups of banks, 2001-2013

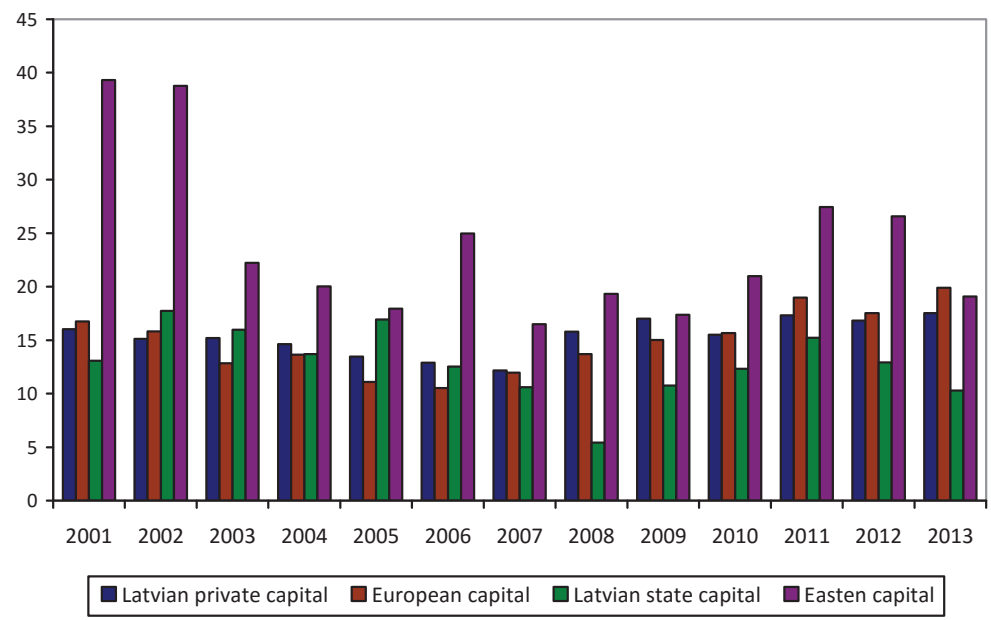

S o u r c e : created by authors based on consolidated annual reports of Latvian banks, 2001-2013.

The greatest risk of Latvian banking sector is credit risk caused mainly by credit portfolio size increase. The group of banks with East capital was able to achieve the highest capital adequacy ratio (on the average during the period 23.91\%), because the specific weight of loans on balance sheets of the group's banks during the analysed period (2001-2013) was small compared to all other groups of banks. Accordingly components of the total amount of credit risk had little impact on amounts of risk-weighted assets in the aforementioned group. In the last quarter of 2013 the capital requirement for credit risk in the banking sector amounted to 1041715 thousand EUR or $89.24 \%$, with dispersion using breakdown in groups of banks from $52.27 \%$ (the group of banks with European capital) to $10.02 \%$ in the group of banks with East capital (Figure 4). 
Figure 4. Breakdown of distribution of mandatory capital requirements for risks in groups of banks, 31.12.2013

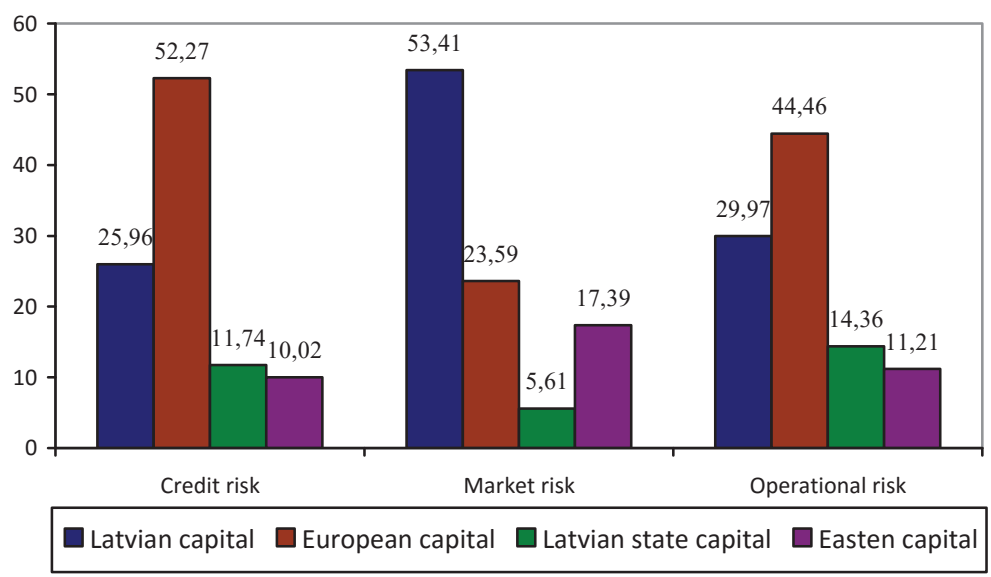

S o u r c e : created by authors based on FCMC data, 2014.

In 2013 only the group of banks with European capital attained the greatest share of credit risk $52.27 \%$ of the market. Banks of this group are more focused on providing services to local customers and especially lending, thus asignificant part of their credit portfolios constitute loans to residents. That explains the great specific weight of credit risk in these banks. Although during the last years the quality of bank credit portfolio continued to improve, credit risk is still considerable. That is related to echoes of events of 2008 , when their borrowers fell victims to sudden insolvency. But considering the fact that the aforementioned banks were leaders in lending, especially mortgage lending; banks in the group of banks owned by European shareholders have suffered the most significant decrease of credit portfolio and the greatest losses. In addition banks focused on non-resident business do not engage to such extent in lending activities, the specific weight of their credit portfolio in their assets is roughly half as big as that of universal banks (full service banks).

\section{IMPACT OF BASEL III REQUIREMENTS ON CAPITAL ADEQUACY OF LATVIAN BANKING SECTOR}

Examination of impact of introducing Basel III requirements on capital adequacy ratios of Latvian banks, first of all, includes evaluation of increase in risk- 
weighted assets of banks. It would not be possible to calculate the total amount of risk-weighted assets of each bank by means of the direct method of Basel III, since financial statements do not contain sufficient data required for calculations. Therefore analysis was performed by means of the indirect method using quantitative change ratios published in the Basel research.

Changes in risk-weighted assets affect also capital adequacy of each group of banks. Figure 5 shows breakdown of changes in Tier 1 capital adequacy in groups of Latvian banks after introduction of Basel III requirements. A new regulatory requirement of $6 \%$ is also introduced for this ratio.

Figure 5. Breakdown of Tier 1 capital adequacy changes in groups of banks

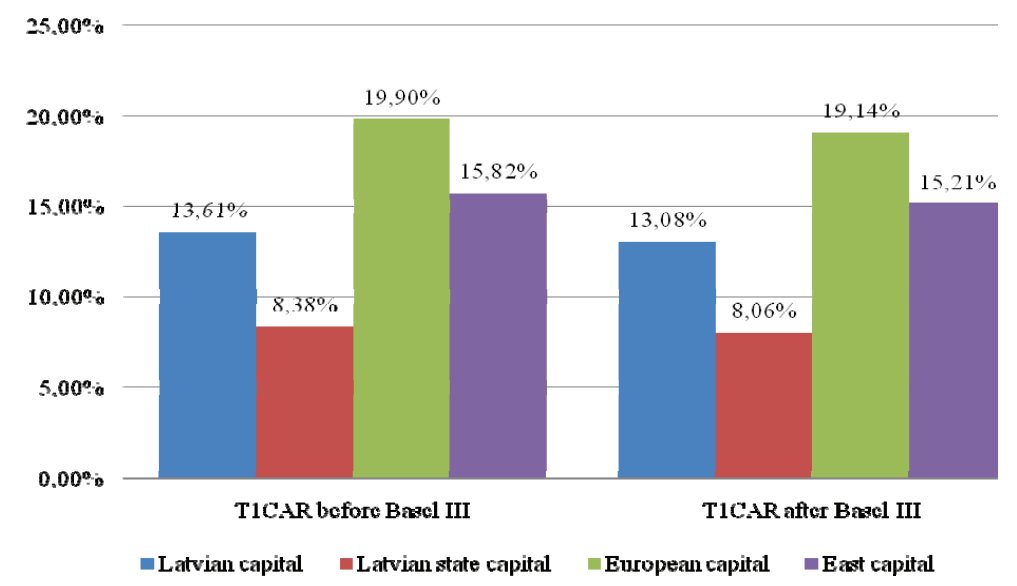

S o u r c e : created by authors based on consolidated annual reports of Latvian banks, 2013.

Evaluation of Tier 1 capital adequacy changes shows that Latvian banks in general will be able to ensure sufficient capital adequacy. Each group of banks will satisfy Basel III requirements though the result will be greatly dispersed among groups of banks. The group of banks with European capital will be ahead of other groups of banks, since their Tier 1 capital adequacy will drop by $0.77 \%$, thus ensuring the highest result $19.14 \%$. The result of the group of banks with Latvian state capital may be worse. Capital adequacy ratio of this group of banks will decrease only a little, by $0.32 \%$, but adequacy of Tier 1 capital will be at critical level $8.06 \%$. Groups of banks with East and Latvian capital will loose on the average $1.13 \%$. Thus each group of banks will be able to ensure Tier 1 capital ratio of $6 \%$, maintaining also a considerable reserve on the 
average over $7.87 \%$, and ensure compliance with the common equity adequacy standard in the mount of 7\% (including 2,5\% buffer). Examination of changes in total capital adequacy helps to evaluate fully changes in capital adequacy ratios after introducing Basel III in the banking sector (Figure 6). Total capital adequacy shows similar tendencies to Tier 1 capital adequacy ratios. The group of banks with European capital will be able to ensure the highest capital adequacy level (19.14\%) with reduction ratio $0.77 \%$. The situation of the group of banks with Latvian state capital will be critical as their capital adequacy after introduction of Basel III will decrease by $0.40 \%$, thus the group's capital adequacy will be at $9.89 \%$ (the standard is $10.50 \%$ ). Capital adequacy of groups of banks with Latvian and East capital will decrease by $1.40 \%$ on the average, and their capital adequacy ratio will exceed $17 \%$.

Figure 6. Breakdown of total capital adequacy changes in groups of banks

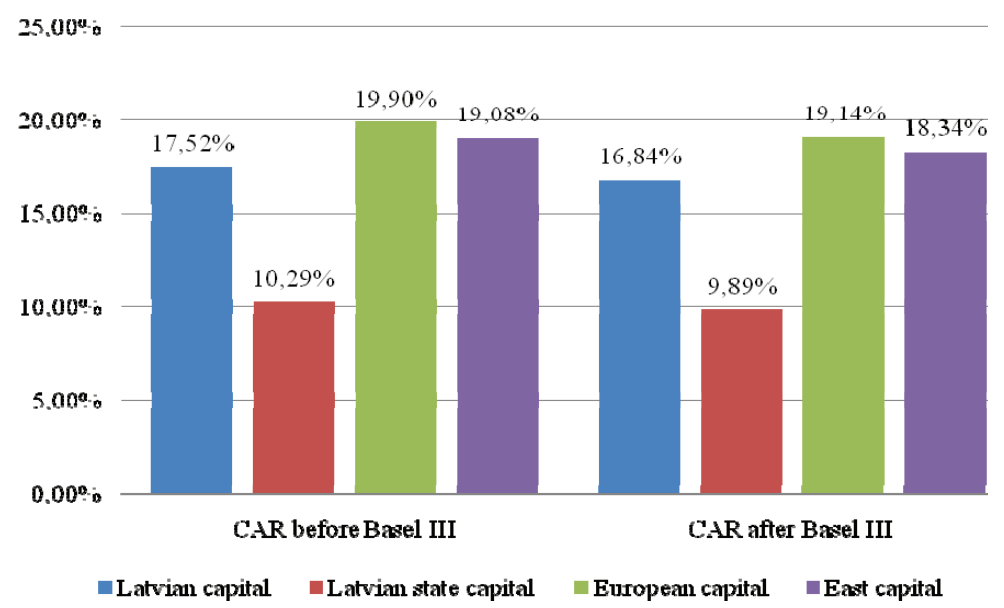

S o u r c e : created by authors based on consolidated annual reports of Latvian banks, 2013.

In 2019 according to new regulations equity capital adequacy ratio of every bank must be at least $10.50 \%$. Respectively, after applying the new regulatory standards to the current indices of financial activities (2013) Latvian banks will be able to satisfy this ratio as well. Changes of each ratio in each group of banks are dispersed differently, but it is clear that as a result of introducing the new Basel III requirements capital adequacy of banks will drop (Table 2). 
Table 2. Breakdown of changes in Tier 1 capital and equity capital adequacy ratios of Latvian banks in groups of banks

\begin{tabular}{|l|c|c|}
\hline \hline \multicolumn{1}{|c|}{$\begin{array}{c}\text { Grouping of Latvian banks } \\
\text { by the capital's origin country }\end{array}$} & $\begin{array}{c}\text { Changes in Tier 1 capital adequacy } \\
\text { after introducing Basel III }\end{array}$ & $\begin{array}{c}\text { Changes in equity capital adequacy } \\
\text { after introducing Basel III }\end{array}$ \\
\hline \hline $\begin{array}{l}\text { Latvian banks with European share- } \\
\text { holders' investments in their capital }\end{array}$ & $-0,77 \%$ & $-0,77 \%$ \\
\hline $\begin{array}{l}\text { Latvian banks with Latvian sharehol- } \\
\text { ders' investments in their capital }\end{array}$ & $-0,52 \%$ & $-0.67 \%$ \\
\hline $\begin{array}{l}\text { Latvian banks with State sharehol- } \\
\text { ders' investments in their capital }\end{array}$ & $-0,32 \%$ & $-0,40 \%$ \\
\hline $\begin{array}{l}\text { Latvian banks with East shareholders' } \\
\text { investments in their capital }\end{array}$ & $-0,61 \%$ & $-0,73 \%$ \\
\hline \hline
\end{tabular}

S o u r c e : created by authors based on consolidated annual reports of Latvian banks, 2013.

Regardless of the conclusion made as a result of the performed analysis that each group of banks already is in a position to satisfy Basel III requirements for capital adequacy, results of the analysis show that two Latvian commercial banks presently will not be able to ensure the required capital adequacy indices (Table 3).

Evaluation results of the commercial bank X (State capital) indicate that the bank's equity capital adequacy would not exceed 9.89\%, respectively $0.61 \%$ under the new capital adequacy standard (10.5\%). Upon evaluation of the commercial bank Y from the East group one must conclude that this bank fails to satisfy Basel III capital adequacy regulations as well. Tier 1 capital adequacy ratio does not reach the standard by $0.71 \%$, the total capital adequacy ratio, in its turn, is $2.79 \%$ lower than the standard (10.50\%).

Table 3. Conformity of capital adequacy ratios of the commercial bank X (Latvian State capital) and the commercial bank Y (Eastern capital) to Basel III requirements

\begin{tabular}{|l|c|c|}
\hline \multicolumn{1}{|c|}{ Name of the bank } & $\begin{array}{c}\text { Commercial bank X } \\
\text { (Latvian State capital) }\end{array}$ & $\begin{array}{c}\text { Commercial bank Y } \\
\text { (Eastern capital) }\end{array}$ \\
\hline \hline Reported period (year) & 2013 Basel III requirements & 2013 Basel III requirements \\
\hline Tier 1 capital (000 EUR) & 94920 & 23527 \\
\hline Equity capital (000 EUR) & 116492 & 34273 \\
\hline Risk-weighted assets (000 EUR) & 1177580 & 444562 \\
\hline
\end{tabular}




\begin{tabular}{|l|c|c|}
\hline \multicolumn{1}{|c|}{ Name of the bank } & \multicolumn{1}{|c|}{$\begin{array}{c}\text { Commercial bank X } \\
\text { (Latvian State capital) }\end{array}$} & $\begin{array}{c}\text { Commercial bank Y } \\
\text { (Eastern capital) }\end{array}$ \\
\hline \hline $\begin{array}{l}\text { Tier 1 capital against risk-weighted } \\
\text { assets, standard (\%) }\end{array}$ & $6,00 \%$ & $6,00 \%$ \\
\hline $\begin{array}{l}\text { Tier 1 capital against risk-weighted } \\
\text { assets, actual (\%) }\end{array}$ & $8,06 \%$ & $-0,71 \%$ \\
\hline Reserve (\%) & $2,06 \%$ & $7,71 \%$ \\
\hline $\begin{array}{l}\text { Equity capital against risk-weighted } \\
\text { assets, actual (\%) }\end{array}$ & $9,89 \%$ & $10,50 \%$ \\
\hline $\begin{array}{l}\text { Equity capital against risk-weighted } \\
\text { assets, standard (\%) } \\
\text { (the so-called buffer) }\end{array}$ & $10,50 \%$ & $-2,79 \%$ \\
\hline Reserve (\%) & & $-0,61 \%$ \\
\hline \hline
\end{tabular}

S o u r c e : created by authors based on consolidated annual reports of Latvian banks, 2013.

\section{FinAl REMARKS AND CONCLUSIONS}

Results of the research allow the authors to make the following conclusions:

1. Basel III rules envision setting stricter requirements for the size of common equity and gradual increase of requirements for minimum capital adequacy ratios and risk evaluation until 2019. Badly prepared commercial banks will not be able to comply with the new Basel III requirements, and that could lead to reduction of the number of banks.

2. The average capital adequacy ratio of Latvian commercial banks satisfies Basel Committee's requirements (at the end of 2013 equity capital adequacy amounted to $16.70 \%$ (2012 - 18.16\%)).

3. In 2013 Tier 2 capital of Latvian banking sector did not exceed $15.22 \%$ (2012 - 13.89\%) share of the total equity capital. But from 2001 to 2009 the amount of subordinated debt was on rapid increase and in 2009 had reached $21.78 \%$ (subordinated capital during the period of time from 2001 to 2009 grew by 566 million EUR). The present low specific weight of subordinated capital in Latvian commercial banks is tied to repayment tendencies of subordinated obligations.

4. From the point of view of grouping of commercial banks by the ownership of their capital, the lowest equity capital adequacy at the end of 2013 had banks founded with state capital - 10.29\% (2012 - 12.92\%), 
but the highest - banks with European (19.90\%) and East (19.08\%) capital (2012 - 17.53\% and 26.57\%, respectively).

5. The analysis of the impact of Basel III requirements on capital adequacy ratios of Latvian commercial banks showed that banks already maintain them at the level of new standards taking into consideration the additional mandatory capital reserve (10.5\%). The group of banks with Latvian state capital was only partially able to satisfy the new Basel III standards and ensure equity capital adequacy only at $9.89 \%$.

6. Groups of banks with East and European capital have the highest equity capital adequacy results according to Basel III requirements $(18.34 \%$ and $19.14 \%$ ).

7. The analysis of impact of introducing Basel III requirements on Latvian banking sector demonstrates that on the average Tier 1 capital adequacy ratio will decrease by $0.32 \%$ (group of banks with State capital) to $0.77 \%$ (group of banks with European capital), the equity capital adequacy ratio in its turn will decrease by $0,40 \%$ (group of banks with State capital) to $0.77 \%$ (group of banks with European capital).

8. One should also note that based on data of 2013 the ability of two Latvian commercial banks (State capital and East capital) to comply with the new Basel III requirements is under doubt. This can be explained by insufficiency of own funds in the capital of commercial banks to cover the increased volume of risk-generating assets.

Based on the research and the conclusions made, the authors have developed the following proposals.

\section{For Latvian commercial banks:}

1. Banks should calculate each month Tier 1 capital and equity capital adequacy ratios to ensure thorough control of their capital adequacy levels according to the present (Basel II) and future (Basel III) regulatory requirements. That will help the banks to identify in a timely manner factors affecting their capital adequacy and prevent their negative impact.

2. Commercial banks should ensure constant supervision of the volume of risk-generating assets and tighten the control of introduced capital ratios and their adequacy changes based on Basel III requirements. The supervision will help to quickly identify factors and circumstances having negative impact on changes of capital adequacy ratios. 
3. Banks should ensure evaluation of their capital adequacy by means of stress situation modelling according to their internal procedures and procedures of supervisory institutions (FCMC and Basel Committee) to identify weaknesses in the bank's capital and assets' structure.

4. At least once a year review their capital and risk management policies.

5. With the increase of profit of commercial banks use the possibility to increase the equity capital from internal sources of the commercial bank, for example, by means of capitalisation.

6. To reduce the credit risk, which has the greatest impact on capital adequacy ratios, the quality of credit portfolio management should be improved by strengthening the credit monitoring and introducing stricter evaluation requirements of borrowers' creditworthiness. To this aim in a timely manner and on a regular basis review and update internal methodologies of the bank for evaluation of borrowers' creditworthiness, use loan interest rate reviewing method, sale of property taken over by the bank to increase the money flow and partially reduce riskgenerating assets.

7. Commercial banks operating actively on the non-residents market, especially in countries with high country risk, should perform detailed analysis of such regions and increase the capital reserve, if necessary, depending on the country risk level of placement country of assets. It is a required step, since according to Basel requirements assets located in high risk regions are applied higher ratios used to determine the amount of risk-weighted assets.

8. To achieve consistency between a bank's risks and capital required to cover them, commercial banks as they accumulate historical data must develop and approve risk evaluation methods based on internal ratings of the commercial bank.

Additionally for the commercial bank Y from the group of banks with East capital:

9. Based on results of the study indicating that the bank Y could be unable to satisfy the new capital adequacy requirements (Basel III) the author would recommend for the bank to perform on a constant basis analysis of the balance between capital and risks. As the balance approaches the minimum critical mark the bank should use certain sources to increase the capital and implement policies aimed at reducing the amount of risk- 
-generating assets to achieve compliance with capital adequacy standards.

Additionally for the commercial bank X from the group of banks with State capital:

10. To achieve the minimum capital adequacy level, including the mandatory capital reserve $(10.50 \%)$, bank X must increase its equity capital by at least 7,1 million EUR. The increase can be attained using the following methods:

- attracting a new strategic investor (shareholder), selling the bank;

- attracting subordinated capital resources;

- partially (to an insignificant extent) by capitalizing the profit to increase the capital under the condition that its stable growth will be maintained.

\section{REFERENCES}

Barclays Capital (2010). Basel III Final Document - What's New.

Basel Committee on Banking Supervision, (2004), International Convergence of Capital Measurement and Capital Standards: A Revised Framework. Switzerland: Basel Commitee On Banking Supervision. https://www.bis.org/publ/bcbs128.pdf (accessed: 10.03.2016).

Basel Commitee on Banking Supervision, (2010). Basel III: A global regulatory framework for more resilient banks and banking systems, Switzerland: Basel Commitee on Banking Supervision. https://www.bis.org/publ/bcbs189_dec2010.pdf (accessed: 12.02.2016).

Basel Commitee on Banking Supervision, (2010). Results of the comprehensive quantitative impact study, Switzerland: Basel Commitee on Banking Supervision. https:// www.bis.org/publ/bcbs186.pdf, (accessed: 12.02.2016).

Basel Commitee on Banking Supervision, (2013). About Basel. http://www.bis.org/ bcbs/about.htm (accessed: 8.01.2016).

Bank for International Settlements, Committee on Payment and Settlement Systems, (2003). A glossary of terms used in payments and settlement systems. Switzerland: Bank for International Settlements. https://www.bis.org/publ/cpss00b.pdf (accessed: 8.01.2016).

Cornford, A., (2010). Revising Basel 2: The Impact of the Financial Crisis and Implications for Developing Countries. In: G-24 Discussion Paper Series, UNITED NATIONS CONFERENCE ON TRADE AND DEVELOPMENT. New York and Geneva, June 2010.

European Parliament and Council Directive 2002/87/EK dated by 20.07.2011.

Ferguson, R.W., (2003). Capital standards for banks: the evolving Basel accord, Federal reserve bulletin. www.federalreserve.gov/pubs/bulletin/2003/0903lead.pdf (accessed: 12.02.2016). 
Financial Commission of Market and Capital (FCMC). Legislations documents, statistics of the credit institutions, annual reports. http://www.fktk.lv (accessed: 12.02.2016).

Greuning, H., \& Brajovic Bratanovic, S., (2009). Analyzing banking risk: a framework for assessing corporate governance and risk management. Washington: World Bank.

Kudinska. M., \& Konovalova. N., (2012). The Analysis of Bank Capital Adequacy: the Case of Latvia, Journal of Business Management, No. 6.

Balthazar L., (2006). From Basel 1 to Basel 3. Great Britain: PALGRAVE MACMILLAN. www.palgraveconnect.com/doifinder/10.../978023050117.

Moody's Analytics, (2011. - 2012.). From Basel II to Basel III.

PWC, (2011). Risk \& Capital Management under Basel III, www.pwc.com/gx /en/banking.../basel-iii-programme.pdf (accessed: 07.01.2016).

Rose, S.P., (2002). Commercial Bank Management. McGraw-Hill Higher Education.

Saksonova, S., (2006). Banku darbība. Riga: Latvian Association of Commercial Banks counseling and training center.

Schooner, H.M., \& Taylor, M., (2009). Regulation of Global Banking: Principles and Policies. Chicago: Academic Press. 